OPEN ACCESS

Edited by:

Antonio Heredia,

University of Malaga,

Spain

Reviewed by:

Rafael Fernández-Muñoz, Consejo Superior de Investigaciones

Científicas (CSIC), Spain

Federico Scossa,

Council for Agricultural and

Economics Research, Italy

*Correspondence:

Christophe Rothan

christophe.rothan@inrae.fr

Specialty section:

This article was submitted to

Plant Physiology,

a section of the journal

Frontiers in Plant Science

Received: 16 September 2021 Accepted: 02 November 2021

Published: 29 November 2021

Citation:

Petit J, Bres C, Reynoud N, Lahaye M, Marion D, Bakan B and Rothan C (2021) Unraveling Cuticle Formation, Structure, and Properties by Using Tomato Genetic Diversity.

Front. Plant Sci. 12:778131.

doi: 10.3389/fpls.2021.778131

\section{Unraveling Cuticle Formation, Structure, and Properties by Using Tomato Genetic Diversity}

\author{
Johann Petit', Cécile Bres ${ }^{1}$, Nicolas Reynoud ${ }^{2}$, Marc Lahaye², Didier Marion², \\ Bénédicte Bakan ${ }^{2}$ and Christophe Rothan ${ }^{\text {t* }}$
}

${ }^{1}$ INRAE, Univ. Bordeaux, UMR BFP, Villenave d'Ornon, France, ${ }^{2}$ Unité Biopolymères, Interactions, Assemblages, INRAE, Nantes, France

The tomato (Solanum lycopersicum) fruit has a thick, astomatous cuticle that has become a model for the study of cuticle formation, structure, and properties in plants. Tomato is also a major horticultural crop and a long-standing model for research in genetics, fruit development, and disease resistance. As a result, a wealth of genetic resources and genomic tools have been established, including collections of natural and artificially induced genetic diversity, introgression lines of genome fragments from wild relatives, high-quality genome sequences, phenotype and gene expression databases, and efficient methods for genetic transformation and editing of target genes. This mini-review reports the considerable progresses made in recent years in our understanding of cuticle by using and generating genetic diversity for cuticle-associated traits in tomato. These include the synthesis of the main cuticle components (cutin and waxes), their role in the structure and properties of the cuticle, their interaction with other cell wall polymers as well as the regulation of cuticle formation. It also addresses the opportunities offered by the untapped germplasm diversity available in tomato and the current strategies available to exploit them.

Keywords: tomato, cuticle, natural diversity, mutant, fruit, cutin, structure, property

\section{INTRODUCTION}

Cultivated tomato (Solanum lycopersicum L.) is a major horticultural crop that has long been a model for the Solanaceae crop species (tomato, potato, eggplant, pepper ...) and for fleshy fruit development and disease resistance (Rothan et al., 2019). Tomato is very suitable for laboratory studies (grown in greenhouse, miniature cultivars, short life cycle, autogamy, and easy genetic transformation) has extensive genetic resources, high-quality reference genome (Tomato Genome Consortium, 2012), sequences of hundreds of accessions (Zhu et al., 2018; Gao et al., 2019; Alonge et al., 2020), and available phenotype and gene expression databases. ${ }^{1}$ Thanks to these resources and tools, genes underlying trait variations can be identified and their relationships with phenotypic variations can be established through in planta functional analysis.

In the last decades, the use of natural diversity available in tomato, such as the ripening mutants ripening inhibitor (rin) or non-ripening (nor), has been instrumental to decipher the

'https://solgenomics.net/ 
regulation of ripening (Klee and Giovannoni, 2011). These advances have been aided by the development of tools for functional analysis of target genes including RNA interference (RNAi) and CRISPR/Cas9 gene editing systems. The molecular determinants of fruit skin formation, which is an essential protective barrier against pests, pathogens, and water loss, have begun to be explored more recently (Vogg et al., 2004; LemaireChamley et al., 2005; Hovav et al., 2007; Mintz-Oron et al., 2008).

Not surprisingly, since the cuticle is a major component of the fruit skin and is associated with a wide diversity of major breeding targets including fruit appearance (color, glossiness, regularity...) and properties (shelf-life, fungal resistance, and cracking; Bargel and Neinhuis, 2005; Petit et al., 2017; Lara et al., 2019), it has received considerable attention in recent years. In this field of study, tomato holds a prominent position among fleshy fruits because of its thick, astomatous, and easyto-peel cuticle (Petit et al., 2017). Additionally, the wide diversity in cuticle architecture and composition found in wild tomato relatives (Yeats et al., 2012a; Halinski et al., 2015; FernandezMoreno et al., 2017) can be exploited for the discovery of novel cuticle-associated genes (Hovav et al., 2007; Zhang et al., 2021). Tomato has therefore become a model for the study of cuticle formation in plants. In the recent years, molecular determinants of cuticle have been identified and genetically altered lines have been produced, enabling the exploration of cuticle structure, properties, interactions with other cell wall components, and relationships with epidermal patterning. Table 1 summarizes the major findings on known tomato cuticleassociated genes, the pathway, or biological process in which they are involved and the main alterations produced by their mutation or de-regulation. This mini-review focuses on the strategies, resources, and tools used to reveal their role, providing examples, and considers future goals and developments.

Linking gene to phenotype can be done using approaches known as (i) reverse genetics in which the function of a target gene is mainly determined by analyzing the phenotype of mutant or deregulated lines and (ii) forward genetics, in which tomato genetic diversity is first screened for phenotypesof-interest and the underlying genes and their function are then identified.

\section{EXPLORING THE FUNCTION OF CUTICLE-ASSOCIATED GENES THROUGH REVERSE GENETICS APPROACHES IN TOMATO}

An obvious source of information on wax- and cutin-associated genes to study in tomato is the model plant Arabidopsis (Bernard and Joubes, 2013; Fich et al., 2016). Examples of the pertinence of this strategy are the conserved functions in Arabidopsis and tomato of the SHINE transcription factors (Shi et al., 2013; Al-Abdallat et al., 2014) and the recent demonstration that the SlABCG42 transporter, the tomato ortholog of the Arabidopsis ABCG PEC1 transporter, is functional and can transport various cutin precursors (Elejalde-Palmett et al., 2021).
For poorly characterized or unknown function genes, the information on where and when they are expressed provides the first cues on their possible role in cuticle formation. Gene expression has been explored in-depth in tomato fruit skin, a tissue which consists of the cuticle, the epidermis, and few layers of collenchyma cells underneath (Bargel and Neinhuis, 2005). Of special interest is the fruit expansion phase, before the onset of ripening, when rapid cuticle deposition occurs (Mintz-Oron et al., 2008; Petit et al., 2014). During the cell expansion phase, ploidy and volume of epidermal and sub-epidermal cells do not vary, whereas ploidy and cell volume undergo a dramatic increase in mesocarp cells (Joubès et al., 1999; Renaudin et al., 2017). In earlier studies, epidermisexpressed genes were identified via tissue-specific Expressed Sequence Tags (EST), microarrays (Lemaire-Chamley et al., 2005; Mintz-Oron et al., 2008), and proteome (Yeats et al., 2010). Several genes highlighted in these studies play prominent roles in cuticle formation, among which the CUTIN SYNTHASE (CUS1) catalyzing cutin polymerization (Girard et al., 2012; Yeats et al., 2012b) and the SIMIXTA-like regulating cuticle formation and epidermal patterning (Lashbrooke et al., 2015). Semi-quantitative RNA-seq coupled with laser microdissection (LMD) next allowed exhaustive inventory of gene transcripts expressed in plant tissues, including outer and inner fruit epidermis (Matas et al., 2011). Another original transcriptomebased approach used a chimera between two tomato species displaying genotype-specific E1 cell layer to provide a reference catalog of epidermis-specific genes (Filippis et al., 2013). Quantitative RNA-seq coupled with LMD later allowed the establishment of a quantitative tomato fruit gene atlas of developing fruit (Shinozaki et al., 2018). The resulting Tomato Expression Database (TEA) available at $\mathrm{SGN}^{2}$ can be mined for clusters of genes co-expressed in specific developmental stages and cell types including inner and outer epidermis, which gives precious information on genes functionally linked to cuticle formation. Gene expression profiling can be further combined with various multi-omics technologies, typically metabolome (Fernandez-Moreno et al., 2016) and proteome (Szymanski et al., 2017), and with large scale sequencing of genetic diversity (Szymański et al., 2020) to assign putative functions to the genes and explore their role in cuticle formation. Novel functions revealed by biochemical approaches, e.g., the cutin:cutin-acid endo-transacylase (CCT) enzyme activity (Xin et al., 2021), may also ultimately lead to the isolation of the encoding gene.

Technologies used for the functional analysis of cuticleassociated genes (Table 1) include Virus-Induced Gene Silencing (VIGS; Ballester et al., 2010; España et al., 2014), stable gene overexpression (e.g., Shi et al., 2013) and silencing via RNA interference (RNAi; e.g., Girard et al., 2012; Lashbrooke et al., 2015) and artificial miRNA (Adato et al., 2009). More recently, the efficient CRISPR/Cas9 system, which allows genome editing of single or multiple target genes (Rothan et al., 2019), has been successfully used to validate the influence of a GA2-oxidase on cuticle formation and fruit firmness (Li et al., 2020). Recent development of genome editing technologies offers the possibility

${ }^{2}$ https://tea.solgenomics.net/ 
TABLE 1 | Genes involved in cuticle formation and properties studied in tomato.*

\begin{tabular}{|c|c|c|c|c|c|c|c|c|}
\hline Gene-locus $^{\mathrm{a}}$ & Solyc ${ }^{b}$ & Type $^{c}$ & Function & Species $^{d}$ & $\begin{array}{l}\text { Cultivar- } \\
\text { accession }\end{array}$ & $\begin{array}{l}\text { Genetic } \\
\text { variation } \\
\text { origin/Allele }^{f}\end{array}$ & $\begin{array}{l}\text { Cuticle- } \\
\text { associated } \\
\text { traits }\end{array}$ & References \\
\hline \multirow[t]{3}{*}{ SICUS1 } & \multirow[t]{3}{*}{$11 \mathrm{~g} 006250$} & \multirow[t]{3}{*}{ Enzyme } & \multirow[t]{3}{*}{$\begin{array}{l}\text { Cutin } \\
\text { polymerization }\end{array}$} & $S I$ & MT & $\begin{array}{l}\text { EMS/gds/2b/ } \\
\text { cus1-a }\end{array}$ & \multirow{3}{*}{$\begin{array}{l}\text { Fruit cuticle } \\
\text { thickness and } \\
\text { properties; cutin } \\
\text { content; } \\
\text { epidermal } \\
\text { patterning; } \\
\text { susceptibility to } \\
\text { pathogens }\end{array}$} & \multirow{3}{*}{$\begin{array}{l}\text { Petit et al., 2014; } \\
\text { Moreira et al., } \\
\text { 2020; Segado } \\
\text { et al., } 2020 \\
\text { Isaacson et al., } \\
\text { 2009; Yeats } \\
\text { et al., 2012b } \\
\text { Girard et al., } \\
\text { 2012; Philippe } \\
\text { et al., 2020a }\end{array}$} \\
\hline & & & & $S I$ & M82 & EMS/cd1/cus1 & & \\
\hline & & & & S/C & WVa106 & RNAi silencing & & \\
\hline SIDCR & 03g025320 & Enzyme & $\begin{array}{l}\text { Cutin } \\
\text { polymerization }\end{array}$ & SI & M82 & RNAi silencing & $\begin{array}{l}\text { Flower and leaf } \\
\text { fusion; fruit } \\
\text { cracking and } \\
\text { suberin formation }\end{array}$ & $\begin{array}{l}\text { Lashbrooke } \\
\text { et al., } 2016\end{array}$ \\
\hline SITTS2 & $12 \mathrm{~g} 006520$ & Enzyme & $\begin{array}{l}\text { Triterpenoid } \\
\text { biosynthesis }\end{array}$ & Sh & LA3917 & Natural & $\begin{array}{l}\text { Fruit cuticle wax } \\
\text { triterpenoids; } \\
\text { amyrin content } \\
\text { and composition }\end{array}$ & $\begin{array}{l}\text { Yeats et al., } \\
2012 a\end{array}$ \\
\hline SICHS1 & 09g091510 & \multirow[t]{2}{*}{ Enzyme } & \multirow{2}{*}{$\begin{array}{l}\text { Flavonoid } \\
\text { biosynthesis }\end{array}$} & \multirow[t]{2}{*}{$S I$} & \multirow[t]{2}{*}{ MT/MM/GD } & \multirow[t]{2}{*}{ VIGS } & \multirow[b]{2}{*}{$\begin{array}{l}\text { Cuticle } \\
\text { composition and } \\
\text { properties; } \\
\text { flavonoid, } \\
\text { polysaccharide, } \\
\text { cutin content and } \\
\text { esters linkage; } \\
\text { epidermal } \\
\text { patterning }\end{array}$} & \multirow{2}{*}{$\begin{array}{l}\text { España et al., } \\
\text { 2014; Heredia } \\
\text { et al., } 2015\end{array}$} \\
\hline SICHS2 & $05 \mathrm{~g} 053550$ & & & & & & & \\
\hline S/SHN1 & $03 g 116610$ & ERF & $\begin{array}{l}\text { Regulation of } \\
\text { wax biosynthesis }\end{array}$ & SI & MM & OE & $\begin{array}{l}\text { Leaf cuticular } \\
\text { wax; plant } \\
\text { drought } \\
\text { resistance }\end{array}$ & $\begin{array}{l}\text { Al-Abdallat et al., } \\
2014\end{array}$ \\
\hline SISHN3 & $06 g 053240$ & ERF & $\begin{array}{l}\text { Regulation of } \\
\text { cutin and wax } \\
\text { biosynthesis }\end{array}$ & $S I$ & MT & OE & $\begin{array}{l}\text { Fruit and leaf cutin } \\
\text { and wax content; } \\
\text { fruit epidermal } \\
\text { patterning; } \\
\text { pathogen } \\
\text { susceptibility }\end{array}$ & $\begin{array}{l}\text { Shi et al., 2013; } \\
\text { Buxdorf et al., } \\
2014\end{array}$ \\
\hline
\end{tabular}


TABLE 1 | Continued

\begin{tabular}{|c|c|c|c|c|c|c|c|c|}
\hline Gene-locus $^{a}$ & Solyc $^{b}$ & Type $^{c}$ & Function & Species $^{d}$ & $\begin{array}{l}\text { Cultivar- } \\
\text { accession }\end{array}$ & $\begin{array}{l}\text { Genetic } \\
\text { variation } \\
\text { origin/Allele }^{f}\end{array}$ & $\begin{array}{l}\text { Cuticle- } \\
\text { associated } \\
\text { traits }\end{array}$ & References \\
\hline SIMIXTA-like & 02g088190 & MYB & $\begin{array}{l}\text { Regulation of } \\
\text { cutin and wax } \\
\text { biosynthesis }\end{array}$ & SI & MT & RNAi silencing & $\begin{array}{l}\text { Fruit cuticle } \\
\text { thickness and } \\
\text { properties; cutin } \\
\text { content; } \\
\text { epidermal } \\
\text { patterning }\end{array}$ & $\begin{array}{l}\text { Lashbrooke } \\
\text { et al., } 2015\end{array}$ \\
\hline WOOLY & 02g080260 & HD-Zip IV & $\begin{array}{l}\text { Regulation of } \\
\text { wax biosynthesis }\end{array}$ & SI & LA3186 & Natural/Wo & $\begin{array}{l}\text { Trichome } \\
\text { initiation; leaf and } \\
\text { fruit wax content }\end{array}$ & $\begin{array}{l}\text { Xiong et al., } \\
2020\end{array}$ \\
\hline SIMYB31 & $03 g 116100$ & MYB & $\begin{array}{l}\text { Regulation of } \\
\text { wax biosynthesis }\end{array}$ & $S I$ & $\mathrm{AC}$ & $\begin{array}{l}\text { RNAi silencing/ } \\
\text { OE }\end{array}$ & $\begin{array}{l}\text { Fruit cuticle } \\
\text { properties; wax } \\
\text { content }\end{array}$ & $\begin{array}{l}\text { Xiong et al., } \\
2020\end{array}$ \\
\hline STICKY PEEL & $01 g 091630$ & HD-Zip IV & $\begin{array}{l}\text { Regulation of } \\
\text { epiderm } \\
\text { metabolism }\end{array}$ & SI & M82 & $\mathrm{EMS} / \mathrm{cd} 2$ & $\begin{array}{l}\text { Fruit and leaf } \\
\text { cuticle properties; } \\
\text { cutin, wax, }\end{array}$ & $\begin{array}{l}\text { Isaacson et al., } \\
\text { 2009; Martin } \\
\text { et al., } 2016\end{array}$ \\
\hline \multirow{2}{*}{$H D-Z I P I V$} & & & & $S I$ & LA0759 & Natural/pe & $\begin{array}{l}\text { flavonoid, } \\
\text { anthocyanin }\end{array}$ & $\begin{array}{l}\text { Kimbara et al., } \\
\text { 2012, } 2013\end{array}$ \\
\hline & & & & $S I$ & LA2467 & & $\begin{array}{l}\text { content and/or } \\
\text { composition; } \\
\text { glandular } \\
\text { trichomes; } \\
\text { pathogen } \\
\text { susceptibility }\end{array}$ & $\begin{array}{l}\text { Nadakuduti } \\
\text { et al., } 2012\end{array}$ \\
\hline YELLOW & $01 \mathrm{g079620}$ & MYB & $\begin{array}{l}\text { Regulation of } \\
\text { flavonoid }\end{array}$ & SI & LA3189 & Natural/y & $\begin{array}{l}\text { Fruit cuticle } \\
\text { thickness and }\end{array}$ & $\begin{array}{l}\text { Adato et al., } \\
2009\end{array}$ \\
\hline \multirow[t]{2}{*}{ PINK FRUIT } & & & metabolism & Sc & LA1480 & Natural/y & $\begin{array}{l}\text { properties } \\
\text { flavonoid }\end{array}$ & $\begin{array}{l}\text { Ballester et al., } \\
2010\end{array}$ \\
\hline & & & & $S I$ & MT & $\mathrm{EMS} / \mathrm{pf}$ & accumulation in & \\
\hline SIMYB12 & & & & & & & $\begin{array}{l}\text { the cuticle; } \\
\text { epidermal } \\
\text { patterning }\end{array}$ & \\
\hline $\begin{array}{l}\text { LYCOPENE } \\
\text { CYCLASE b }\end{array}$ & & Enzyme & $\begin{array}{l}\text { Carotenoid } \\
\text { metabolism }\end{array}$ & $S I$ & $\mathrm{MM}$ & $\begin{array}{l}\text { OE } \\
\text { Arabidopsis } \\
\text { AT3G10230 }\end{array}$ & $\begin{array}{l}\text { Extended shelf- } \\
\text { life; fruit cuticle } \\
\text { thickness and } \\
\text { properties; ABA } \\
\text { content; cutin and } \\
\text { triterpenoid } \\
\text { content }\end{array}$ & $\begin{array}{l}\text { Diretto et al., } \\
2020\end{array}$ \\
\hline SIPP2C3 & 06g076400 & Enzyme & $\begin{array}{l}\text { Regulation of } \\
\text { ABA metabolism }\end{array}$ & SI & MT & $\begin{array}{l}\text { RNAi silencing/ } \\
\text { OE }\end{array}$ & $\begin{array}{l}\text { Fruit cuticle } \\
\text { properties; } \\
\text { epidermal } \\
\text { patterning }\end{array}$ & Liang et al., 2021 \\
\hline GA2-OXIDASE & $10 \mathrm{~g} 007570$ & Enzyme & GA catabolism & SI & LA1310 & Natural/fis1 & $\begin{array}{l}\text { Fruit firmness; } \\
\text { cuticle thickness; } \\
\text { cutin and wax } \\
\text { content }\end{array}$ & Li et al., 2020 \\
\hline TAGL 1 & 07g055920 & MADS box & $\begin{array}{l}\text { Regulation of } \\
\text { fruit ripening }\end{array}$ & SI & $\mathrm{MM}$ & $\begin{array}{l}\text { RNAi silencing/ } \\
\text { OE }\end{array}$ & $\begin{array}{l}\text { Fruit cuticle } \\
\text { thickness and } \\
\text { properties; cutin, } \\
\text { wax, cell wall and } \\
\text { phenolics } \\
\text { composition and } \\
\text { content; } \\
\text { epidermal } \\
\text { patterning }\end{array}$ & $\begin{array}{l}\text { Giménez et al., } \\
2015\end{array}$ \\
\hline RIN & $05 \mathrm{~g} 012020$ & MADS box & $\begin{array}{l}\text { Regulation of } \\
\text { fruit ripening }\end{array}$ & $S I$ & $A C$ & Natural/rin & $\begin{array}{l}\text { Long shelf-life; } \\
\text { fruit cuticle } \\
\text { composition and } \\
\text { properties; cutin } \\
\text { and wax } \\
\text { composition }\end{array}$ & $\begin{array}{l}\text { Kosma et al., } \\
2010\end{array}$ \\
\hline
\end{tabular}


TABLE 1 | Continued

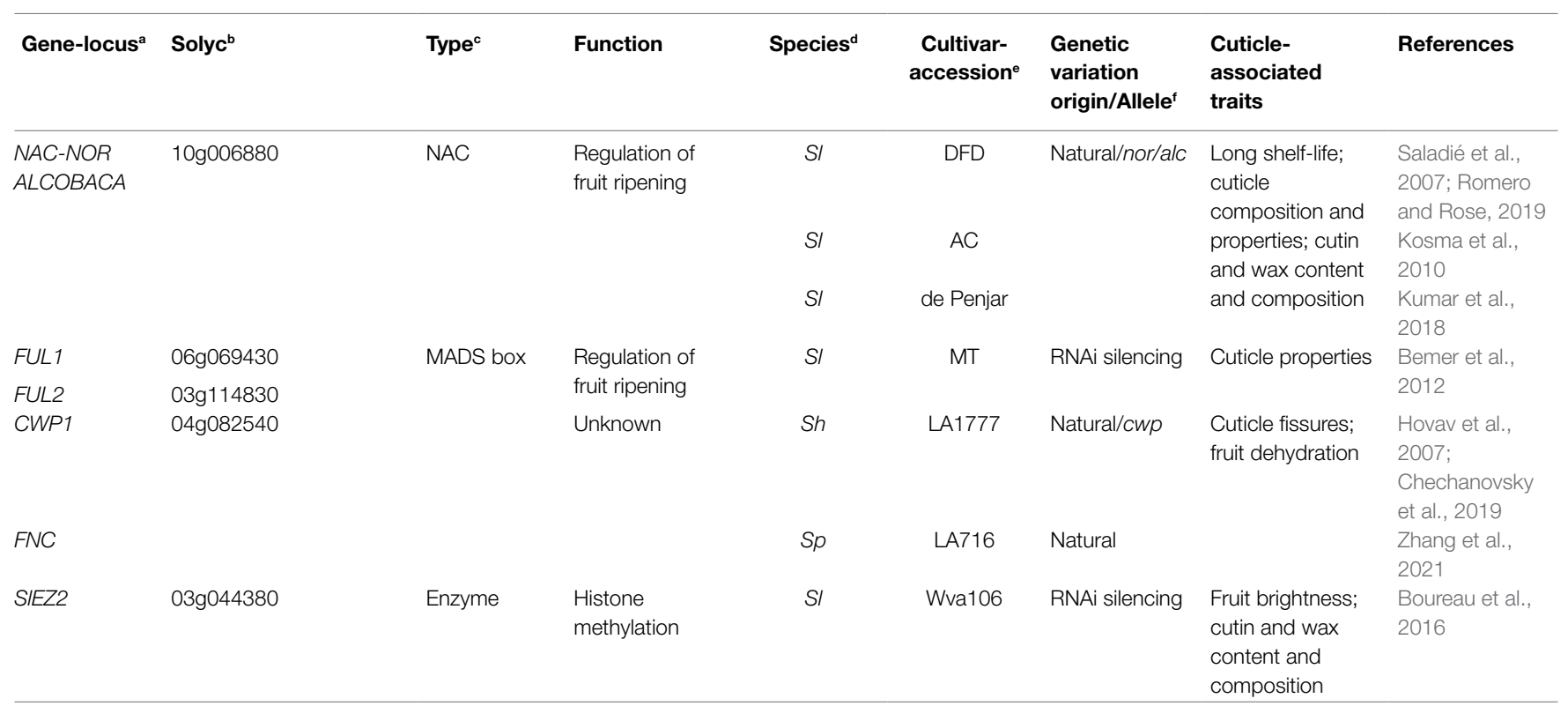

*The table is focused on published studies in which the tomato cuticle was explicitly analyzed, as revealed by an extensive literature review. a Locus and/or gene names are indicated when available in the cited references. CYP, CYTOCHROME P450; GPAT, GLYCEROL-3-PHOSPHATE ACYLTRANSFERASE; ABCG, ATPBINDING CASSETTE (ABC) G; CUS, CUTIN SYNTHASE; CER, ECERIFERUM; KCS, B-KETOACYL-COA-SYNTHASE; DCR, DEFECTIVE IN CUTICULAR RIDGES; TTS, TRITERPENE SYNTHASE; CHS, CHALCONE SYNTHASE; SHN, SHINE; HD-ZIP IN, HOMEODOMAIN-LEUCINE ZIPPER IV; PP2C, PROTEIN PHOSPHATASE 2C; TAGL1, TOMATO AGAMOUSLIKE1; RIN, RIPENING INHIBITOR; NOR, NON-RIPENING; FUL, FRUITFULL; CWP, CUTICULAR WATER PERMEABILITY; AND FNC, FRUIT NETTED CRACKING.

${ }^{b}$ The SGN Solanum lycopersicum (Solyc) identifier is indicated.

${ }^{\circ}$ ERF, Ethylene Response Factor; MYB, HD-Zip, MADS box, and NAC are transcription factors.

¿SI, Solanum Iycopersicum; Slc, Solanum Iycopersicum var. cerasiformae; Sc. Solanum chmielewskii; Sh, Solanum habrochaites; and Sp, Solanum pennellii.

${ }^{\text {e}}$ For natural mutations, the original species and Tomato Genetics Resource Center (TGRC) accession number of the genotype carrying the allelic variant studied are indicated. When not available in the cited references, the background genotype in which the mutation has been introgressed is indicated. MT, Micro-Tom; MM, Moneymaker; AC, Ailsa Craig; and

GD, Gardener's Delight.

${ }^{t} E M S$, Ethyl methane sulfonate; RNAi, RNA interference; and OE, overexpression. The various names of the induced or natural alleles are indicated.

to specifically target cuticle genes in the fruit (Feder et al., 2020) when rapid cuticle deposition takes place (Mintz-Oron et al., 2008) by using the fruit- and expansion phase-specific promoter proPPC2 (Fernandez et al., 2009; Guillet et al., 2012). This further opens the perspective to specifically edit a cuticle gene in fruit epidermis, for instance by employing the promoter from the wax biosynthesis SlCER6 gene (Vogg et al., 2004) that drives reporter expression in both inner and outer fruit epidermis (Mintz-Oron et al., 2008).

\section{DISCOVERING CUTICLE-ASSOCIATED GENES THROUGH FORWARD GENETICS APPROACHES IN TOMATO}

Though the list of cuticle-associated genes can be considerably shortened by mining existing databases and literature, their systematic analysis in planta may remain problematic because of gene redundancy, pleiotropic effect, etc. This may restrict the focus to known gene families, thus impeding the discovery of original gene functions. An alternative approach is to screen natural or artificially induced genetic diversity for phenotypesof-interest, e.g., fruit surface defects induced by cutin deficiency (Isaacson et al., 2009; Petit et al., 2014), and then identify causal genetic variation.

\section{Using Natural Genetic Diversity for Linking Cuticle Phenotype to Gene}

Wild tomato species are an important source of genes lost during domestication of tomato (Gao et al., 2019). The main tomato germplasm repository, from which seeds can be ordered, is the Tomato Genetics Resource Center (TGRC). ${ }^{3}$ It includes the phenotypic description of wild tomato relatives and of thousands of cultivated tomato accessions carrying spontaneous or artificially induced mutations. Natural diversity can be screened for cuticle structure and composition (Yeats et al., 2012a; Halinski et al., 2015), transpirational water loss (Fich et al., 2020), and for mutations, such as positional sterile ( $p s)$, which causes organ fusion by affecting the wax decarboxylation pathway (Leide et al., 2011) or yellow (y) resulting from a SlMYB12 mutation (Adato et al., 2009; Ballester et al., 2010).

Most wild tomato relatives are easily crossed with tomato to generate segregating populations, e.g., the Solanum pimpinellifoliumderived population (Barraj Barraj et al., 2021), thus allowing the detection of cuticle Quantitative Trait Locus (QTL) and candidate genes. Genomic regions of wild species can be further fixed in an uniform S. lycopersicum genetic background to produce Introgression Lines (Ils) or Backcross Inbred Lines (BIls; Bazakos

${ }^{3}$ https://tgrc.ucdavis.edu 
et al., 2017; Petit et al., 2017). The most extensively used ILs, derived from Solanum pennellii (Eshed and Zamir, 1995), enabled the rapid mapping of cuticle-associated QTLs and genes for leaf waxes (Ofner et al., 2016), wax alkane and amyrin content (Fernandez-Moreno et al., 2017), epidermal reticulation of green fruit (Cui et al., 2017), and fruit skin microfissuring (Zhang et al., 2021). Large scale transcriptome and metabolome analysis of fruit skin from 580 inbred lines further identified genes involved in flavonoid biosynthesis and fungal resistance (Szymański et al., 2020). Solanum habrochaites-derived lines allowed the identification of candidate genes for wax triterpenoids (Yeats et al., 2012a) and the isolation of the CWP1 gene of unknown function responsible for skin microfissuring (Hovav et al., 2007; Chechanovsky et al., 2019). Solanum chmielewskii ILs were used to identify a $y$ mutant (Ballester et al., 2010).

The effects on cuticle formation of natural genetic variants found in cultivated tomato were also explored. STICKY PEEL encodes a HD-Zip IV protein that regulates epidermis metabolism and additional cuticle-associated traits (Kimbara et al., 2012; Nadakuduti et al., 2012) while WOOLY, a different HD-Zip IV protein, regulates trichome initiation and wax biosynthesis (Xiong et al., 2020). GA2-OXIDASE, which was identified through a fruit firmness QTL analysis, is unexpectedly related to a cuticle thickness QTL (Li et al., 2020) and connects cuticle formation with gibberellin (GA) signaling. In addition, because of the strong impact of cuticle properties on tomato postharvest storage (Saladié et al., 2007), lines harboring the well-studied non-ripening mutations rin and nor (Wang et al., 2020) as well as several long shelf-life tomato varieties ["Delayed Fruit Deterioration" (DFD) cultivar., de Penjar types] carrying allelic variants of NAC-NOR (e.g., alcobaca) have been characterized with respect to cuticle composition and properties (Saladié et al., 2007; Kosma et al., 2010; Kumar et al., 2018; Romero and Rose, 2019). The complex interplay between fruit development and ripening, epidermal patterning and metabolism, and cuticle formation and properties, which was revealed by these studies, was further supported by independent studies of the ripening regulators FUL1/FUL2 (Bemer et al., 2012) and TAGL1 (Giménez et al., 2015).

\section{Using Artificially Induced Genetic Diversity for Linking Cuticle Phenotype to Gene}

Several collections of artificially induced genetic diversity have been generated in cultivated tomato by transposon tagging (Meissner et al., 1997) or ethyl methanesulfonate (EMS) mutagenesis (Menda et al., 2004; Minoia et al., 2010; Saito et al., 2011; Just et al., 2013; Gupta et al., 2017). The two main mutagenized cultivars are the miniature Micro-Tom tomato (Meissner et al., 1997), which is well suited for laboratory use (Meissner et al., 1997; Just et al., 2013), and M82 (Menda et al., 2004), a processing tomato parent of the widely used S. pennellii ILs (Eshed and Zamir, 1995). Several cutin-deficient mutants were found in the M82 mutant collection (Isaacson et al., 2009) while more than 10 wax-altered and/or cutindeficient glossy mutants were described in Micro-Tom (Petit et al., 2014). Many more mutants can be found by screening tomato mutant collections for obvious cuticle defects (Petit et al., 2014) and by browsing associated phenotypic databases (reviewed in Rothan et al., 2016), such as TOMATOMA ${ }^{4}$ (Saito et al., 2011). EMS mutant collections can also be screened by TILLING (Targeting Induced Local Lesions IN Genomes; Okabe et al., 2011) though mutated alleles of target genes are now efficiently generated by gene editing (Rothan et al., 2019).

As detailed in Table 1, mutant collections have been instrumental for: (i) discovering novel gene functions (SlCUS1; Yeats et al., 2012b); (ii) isolating allelic variants of genes implicated in wax biosynthesis (SlCER6; Vogg et al., 2004; Smirnova et al., 2013), cutin biosynthesis (SlCYP86A69; Shi et al., 2013; SlGPAT6; Petit et al., 2016) and polymerization (SlCUS1; Petit et al., 2014), and regulation of flavonoid biosynthesis (SIMYB12; Fernandez-Moreno et al., 2016); and (iii) deciphering the regulation of epidermis (HD-Zip IV; Isaacson et al., 2009).

\section{CONCLUDING REMARKS AND PERSPECTIVES}

Thanks to its thick astomatous fruit cuticle that is easy to study and the wealth of mutants and lines with altered expression of cuticle-related genes already available, tomato provides an excellent model for deciphering the molecular determinants of cuticle formation, structure, and properties. As detailed in Table 1, reverse and forward genetics approaches led to the isolation of tomato genes involved in several cuticle-associated biosynthetic pathways including wax biosynthesis (SlCER6, SLTTS1, and SlTTS2); cutin biosynthesis (SlCYP86A69 and SlGPAT6), transport (SlABCG36/42), and polymerization (SlCUS1 and SlDCR); and flavonoid biosynthesis (SlCHS1 and SlCHS2). Besides genes encoding various transcription factors (SISHN1 and SISHN3, SIMIXTA-like, two HD-Zip IV, SIMYB31, and SIMYB12) or related to ABA (LYCOPENE CYCLASE $b$ and SIPP2C3) and GA (GA2-OXIDASE) hormonal pathways were shown to regulate cuticle formation and its coordination with epidermal patterning.

Altogether these studies demonstrated the interest of both reverse and forward genetic approaches for discovering novel cuticle gene functions and for generating new plant material to study in-depth cuticle architecture, properties, and interaction with other cell wall components. To face new challenges in cuticle studies, several research avenues can be envisaged in the next future. Analysis of key cuticle genes should be extended to additional family members not yet analyzed for their role in cuticle deposition. An example is that of the GDSL-domain family to which belongs the cutin synthase CUS1 enzyme, whose function was discovered and confirmed through convergent studies in tomato (Table 1). The expression of different CUS1 homologs is deregulated, sometimes oppositely, in several cutin-deficient mutants (Lashbrooke et al., 2015; Petit et al., 2016). By analogy with the recently demonstrated role of GDSL-domain proteins in suberin formation (Ursache et al., 2021), CUS1 homologs (Yeats et al., 2014) may fulfill opposite functions of cutin polymerization and degradation in fruit skin, thereby adapting

${ }^{4}$ https://tomatoma.nbrp.jp/ 
cuticle formation to rapid fruit growth. Particular attention should also be given to enzymes from the poorly explored phenolic pathway in the epidermis which has evolutionary conserved roles in cuticle properties (Philippe et al., 2020b; Kriegshauser et al., 2021) and to proteins involved in the modification of cell wall polysaccharides (Philippe et al., 2020a). Cell wall enzymes and other proteins likely play central roles in cuticle structure and properties and in the coordination of cuticle deposition with organ development and epidermal patterning (Philippe et al., 2020b). So far, few studies have linked cuticle formation in tomato with hormones, except for ABA (Diretto et al., 2020; Liang et al., 2021) and GA (Li et al., 2020). The role of ABA is not surprising considering the importance of $\mathrm{ABA}$ signaling in the response to various stresses (Curvers et al., 2010; Liang et al., 2021), as established in tomato leaves (Martin et al., 2017). More unexpected is the role of GA, the effect of which on cuticle formation is far from being understood (Li et al., 2020). In view of its numerous roles in plant defense and development (Fenn and Giovannoni, 2021), ethylene is also a likely candidate for regulating cuticle formation in tomato fruit. The selection of new "guilt-by-association" target genes for these pathways and processes can be considerably aided by literature mining and/or exploitation of various genomic data (transcriptome, proteome, and metabolome) including co-expression analyses across various fruit cell types and developmental stages (Shinozaki et al., 2018) and across various plant species (Lashbrooke et al., 2016).

In addition to the approaches described above, which often requires previous knowledge of the gene, pathway or process to be targeted, the exploration of untapped genetic diversity, for example, tomato landraces (Conesa et al., 2020), is a way to get off the beaten tracks. This can be very rewarding but also lead to the isolation of challenging genes with no obvious or demonstrated link to the cuticle ( $\mathrm{Li}$ et al., 2020), or even unknown function (Hovav et al., 2007). One bottleneck in such approach is the phenotyping of large collections (Petit et al., 2017). It can be easy for obvious cuticular defects (Hovav et al., 2007), more challenging for less evident changes (Petit et al., 2014), and complex when low or medium throughput technologies are required, e.g., for wax and cutin monomer analyses (FernandezMoreno et al., 2017). In the recent years, high resolution genotyping, whole genome sequencing-based strategies, such as mapping-by-sequencing (MBS) or QTL-seq (Garcia et al., 2016;

\section{REFERENCES}

Adato, A., Mandel, T., Mintz-Oron, S., Venger, I., Levy, D., Yativ, M., et al. (2009). Fruit-surface flavonoid accumulation in tomato is controlled by a SIMYB12-regulated transcriptional network. PLoS Genet. 5:e1000777. doi: 10.1371/journal.pgen.1000777

Al-Abdallat, A. M., Al-Debei, H. S., Ayad, J. Y., and Hasan, S. (2014). Overexpression of SISHN1 gene improves drought tolerance by increasing cuticular wax accumulation in tomato. Int. J. Mol. Sci. 15, 19499-19515. doi: 10.3390/ ijms151119499

Alonge, M., Wang, X., Benoit, M., Soyk, S., Pereira, L., Zhang, L., et al. (2020). Major impacts of widespread structural variation on gene expression and crop improvement in tomato. Cell 182, 145.e23-161.e23. doi: 10.1016/j.cell.2020.05.021

Ballester, A. R., Molthoff, J., de Vos, R., Hekkert, B. L., Orzaez, D., Fernández-Moreno, J. P., et al. (2010). Biochemical and molecular analysis
Bazakos et al., 2017), accelerated gene isolation in tomato (Rothan et al., 2019). However, though identifying the causal mutation can be relatively straightforward in EMS mutants (Garcia et al., 2016), isolating causal genetic variations from natural diversity can be complex since it usually requires crossing the genotypeof-interest with a distant genotype. The subsequent co-segregation in the progeny of numerous cuticle traits unrelated to the traitof-interest may make phenotyping very difficult and even prohibit high resolution mapping of the genetic variant (Rothan et al., 2016). Association mapping has emerged in the last decade as a powerful tool to discover linkages between gene polymorphism and variations in fruit traits by exploring natural genetic diversity. In tomato, sequencing of hundreds of accessions combined with fruit phenotyping pinpointed genetic variations associated with changes in fruit size, flavor, and color among which SIMYB12 polymorphisms responsible for pink fruit color (Zhu et al., 2018). More recently, pan-genome analysis of hundreds of wild and cultivated tomato accessions further uncovered numerous unknown genes and genetic variations underlying fruit traits (Gao et al., 2019; Alonge et al., 2020). Phenotyping selected panels of sequenced accessions for cuticle-associated traits should yield numerous genetic variations controlling cuticle and skin formation and properties, and help identifying new functions involved in these processes. In addition to the genetic control of cuticle formation, the epigenetic regulation of wax and cutin biosynthesis will be worth exploring in the near future, as a preliminary study has shown that altering histone methylation status has a profound effect on the composition of tomato fruit cuticle (Boureau et al., 2016; Table 1).

\section{ACCESSION NUMBERS}

Sequence data from this article can be found in the SGN database under accession numbers found in Table $\mathbf{1}$.

\section{AUTHOR CONTRIBUTIONS}

CR wrote the manuscript. $\mathrm{CB}$ and $\mathrm{DM}$ revised and edited the manuscript. All authors contributed to the article and approved the submitted version.

of pink tomatoes: deregulated expression of the gene encoding transcription factor SIMYB12 leads to pink tomato fruit color. Plant Physiol. 152, 71-84. doi: $10.1104 /$ pp.109.147322

Bargel, H., and Neinhuis, C. (2005). Tomato (Lycopersicon esculentum mill.) fruit growth and ripening as related to the biomechanical properties of fruit skin and isolated cuticle. J. Exp. Bot. 56, 1049-1060. doi: 10.1093/jxb/eri098

Barraj Barraj, R., Segado, P., Moreno-González, R., Heredia, A., Fernández-Muñoz, R., and Domínguez, E. (2021). Genome-wide QTL analysis of tomato fruit cuticle deposition and composition. Hortic. Res. 8:113. doi: 10.1038/s41438-021-00548-5

Bazakos, C., Hanemian, M., Trontin, C., Jiménez-Gómez, J. M., and Loudet, O. (2017). New strategies and tools in quantitative genetics: how to go from the phenotype to the genotype. Annu. Rev. Plant Biol. 68, 435-455. doi: 10.1146/annurev-arplant-042916-040820

Bemer, M., Karlova, R., Ballester, A. R., Tikunov, Y. M., Bovy, A. G., Wolters-Arts, M., et al. (2012). The tomato FRUITFULL homologs TDR4/ 
FUL1 and BP7/FUL2 regulate ethylene-independent aspects of fruit ripening. Plant Cell 24, 4437-4451. doi: 10.1105/tpc.112.103283

Bernard, A., and Joubes, J. (2013). Arabidopsis cuticular waxes: advances in synthesis, export and regulation. Prog. Lipid Res. 52, 110-129. doi: 10.1016/j. plipres.2012.10.002

Boureau, L., How-Kit, A., Teyssier, E., Drevensek, S., Rainieri, M., Joubès, J., et al. (2016). A CURLY LEAF homologue controls both vegetative and reproductive development of tomato plants. Plant Mol. Biol. 90, 485-501. doi: 10.1007/s11103-016-0436-0

Buxdorf, K., Rubinsky, G., Barda, O., Burdman, S., Aharoni, A., and Levy, M. (2014). The transcription factor SISHINE3 modulates defense responses in tomato plants. Plant Mol. Biol. 84, 37-47. doi: 10.1007/s11103-013-0117-1

Chechanovsky, N., Hovav, R., Frenkel, R., Faigenboim, A., Eselson, Y., Petreikov, M., et al. (2019). Low temperature upregulates cwp expression and modifies alternative splicing patterns, increasing the severity of $c w p$ induced tomato fruit cuticular microfissures. Hortic. Res. 6:122. doi: 10.1038/ s41438-019-0204-9

Conesa, M. À., Fullana-Pericàs, M., Granell, A., and Galmés, J. (2020). Mediterranean long shelf-life landraces: an untapped genetic resource for tomato improvement. Front. Plant Sci. 10:1651. doi: 10.3389/ fpls.2019.01651

Cui, L., Qiu, Z., Wang, Z., Gao, J., Guo, Y., Huang, Z., et al. (2017). Fine mapping of a gene (ER4.1) that causes epidermal reticulation of tomato fruit and characterization of the associated transcriptome. Front. Plant Sci. 8:1254. doi: $10.3389 /$ fpls.2017.01254

Curvers, K., Seifi, H., Mouille, G., de Rycke, R., Asselbergh, B., and Van Hecke, A. (2010). Abscisic acid deficiency causes changes in cuticle permeability and pectin composition that influence tomato resistance to Botrytis cinerea. Plant Physiol. 154, 847-860. doi: 10.1104/pp.110.158972

Diretto, G., Frusciante, S., Fabbri, C., Schauer, N., Busta, L., Wang, Z., et al. (2020). Manipulation of $\beta$-carotene levels in tomato fruits results in increased ABA content and extended shelf life. Plant Biotechnol. J. 18, 1185-1199. doi: $10.1111 /$ pbi.13283

Elejalde-Palmett, C., Martinez San Segundo, I., Garroum, I., Charrier, L., De Bellis, D., Mucciolo, A., et al. (2021). ABCG transporters export cutin precursors for the formation of the plant cuticle. Curr. Biol. 31, 2111. e9-2123.e9. doi: 10.1016/j.cub.2021.02.056

Eshed, Y., and Zamir, D. (1995). An introgression line population of Lycopersicon pennellii in the cultivated tomato enables the identification and fine mapping of yield-associated QTL. Genetics 141, 1147-1162. doi: 10.1093/genetics/141.3.1147

España, L., Heredia-Guerrero, J. A., Reina-Pinto, J. J., Fernández-Muñoz, R., Heredia, A., and Domínguez, E. (2014). Transient silencing of CHALCONE SYNTHASE during fruit ripening modifies tomato epidermal cells and cuticle properties. Plant Physiol. 166, 1371-1386. doi: 10.1104/pp.114.246405

Fawke, S., Torode, T. A., Gogleva, A., Fich, E. A., Sørensen, I., Yunusov, T., et al. (2019). Glycerol-3-phosphate acyltransferase 6 controls filamentous pathogen interactions and cell wall properties of the tomato and Nicotiana benthamiana leaf epidermis. New Phytol. 223, 1547-1559. doi: 10.1111/ nph. 15846

Feder, A., Jensen, S., Wang, A., Courtney, L., Middleton, L., Van Eck, J., et al. (2020). Tomato fruit as a model for tissue-specific gene silencing in crop plants. Hortic. Res. 7:142. doi: 10.1038/s41438-020-00363-4

Fenn, M. A., and Giovannoni, J. J. (2021). Phytohormones in fruit development and maturation. Plant J. 105, 446-458. doi: 10.1111/tpj.15112

Fernandez, A. I., Viron, N., Alhagdow, M., Karimi, M., Jones, M., Amsellem, Z., et al. (2009). Flexible tools for gene expression and silencing in tomato. Plant Physiol. 151, 1729-1740. doi: 10.1104/pp.109.147546

Fernandez-Moreno, J. P., Levy-Samoha, D., Malitsky, S., Monforte, A. J., Orzaez, D., Aharoni, A., et al. (2017). Uncovering tomato quantitative trait loci and candidate genes for fruit cuticular lipid composition using the Solanum pennellii introgression line population. J. Exp. Bot. 68, 2703-2716. doi: $10.1093 /$ jxb/erx134

Fernandez-Moreno, J. P., Tzfadia, O., Forment, J., Presa, S., Rogachev, I., Meir, S., et al. (2016). Characterization of a new pink-fruited tomato mutant results in the identification of a null allele of the SIMYB12 transcription factor. Plant Physiol. 171, 1821-1836. doi: 10.1104/pp.16.00282

Fich, E. A., Fisher, J., Zamir, D., and Rose, J. (2020). Transpiration from tomato fruit occurs primarily via trichome-associated transcuticular polar pores. Plant Physiol. 184, 1840-1852. doi: 10.1104/pp.20.01105
Fich, E. A., Segerson, N. A., and Rose, J. K. (2016). The plant polyester cutin: biosynthesis, structure, and biological roles. Annu. Rev. Plant Biol. 67, 207-233. doi: 10.1146/annurev-arplant-043015-111929

Filippis, I., Lopez-Cobollo, R., Abbott, J., Butcher, S., and Bishop, G. J. (2013). Using a periclinal chimera to unravel layer-specific gene expression in plants. Plant J. 75, 1039-1049. doi: 10.1111/tpj.12250

Gao, L., Gonda, I., Sun, H., Ma, Q., Bao, K., Tieman, D. M., et al. (2019). The tomato pan-genome uncovers new genes and a rare allele regulating fruit flavor. Nat. Genet. 51, 1044-1051. doi: 10.1038/ s41588-019-0410-2

Garcia, V., Bres, C., Just, D., Fernandez, L., Tai, F. W. J., Mauxion, J. P., et al. (2016). Rapid identification of causal mutations in tomato EMS populations via mapping-by-sequencing. Nat. Protoc. 11, 2401-2418. doi: 10.1038/ nprot.2016.143

Giménez, E., Dominguez, E., Pineda, B., Heredia, A., Moreno, V., Lozano, R., et al. (2015). Transcriptional activity of the MADS box ARLEQUIN/TOMATO AGAMOUS-LIKE1 gene is required for cuticle development of tomato fruit. Plant Physiol. 168, 1036-1048. doi: 10.1104/pp.15.00469

Girard, A. L., Mounet, F., Lemaire-Chamley, M., Gaillard, C., Elmorjani, K., Vivancos, J., et al. (2012). Tomato GDSL1 is required for cutin deposition in the fruit cuticle. Plant Cell 24, 3119-3134. doi: 10.1105/tpc.112.101055

Guillet, C., Aboul-Soud, M. A., Le Menn, A., Viron, N., Pribat, A., Germain, V., et al. (2012). Regulation of the fruit-specific PEP carboxylase SIPPC2 promoter at early stages of tomato fruit development. PLoS One 7:e36795. doi: 10.1371/ journal.pone. 0036795

Gupta, P., Reddaiah, B., Salava, H., Upadhyaya, P., Tyagi, K., Sarma, S., et al. (2017). Next-generation sequencing (NGS)-based identification of induced mutations in a doubly mutagenized tomato (Solanum lycopersicum) population. Plant J. 92, 495-508. doi: 10.1111/tpj.13654

Halinski, L. P., Kalkowska, M., Kalkowski, M., Piorunowska, J., Topolewska, A., and Stepnowski, P. (2015). Cuticular wax variation in the tomato (Solanum lycopersicum L.), related wild species and their interspecific hybrids. Biochem. Syst. Ecol. 60, 215-224. doi: 10.1016/j.bse.2015.04.030

Heredia, A., Heredia-Guerrero, J. A., and Domínguez, E. (2015). CHS silencing suggests a negative cross-talk between wax and flavonoid pathways in tomato fruit cuticle. Plant Signal. Behav. 10:e1019979. doi: 10.1080/1559 2324.2015.1019979

Hovav, R., Chehanovsky, N., Moy, M., Jetter, R., and Schaffer, A. A. (2007). The identification of a gene (Cwp1), silenced during Solanum evolution, which causes cuticle microfissuring and dehydration when expressed in tomato fruit. Plant J. 52, 627-639. doi: 10.1111/j.1365-313X. 2007.03265.x

Isaacson, T., Kosma, D. K., Matas, A. J., Buda, G. J., He, Y., Yu, B., et al. (2009). Cutin deficiency in the tomato fruit cuticle consistently affects resistance to microbial infection and biomechanical properties, but not transpirational water loss. Plant J. 60, 363-377. doi: 10.1111/j.1365313X.2009.03969.X

Joubès, J., Phan, T. H., Just, D., Rothan, C., Bergounioux, C., Raymond, P., et al. (1999). Molecular and biochemical characterization of the involvement of cyclin-dependent kinase A during the early development of tomato fruit. Plant Physiol. 121, 857-869. doi: 10.1104/pp.121.3.857

Just, D., Garcia, V., Fernandez, L., Bres, C., Mauxion, J. P., Petit, J., et al. (2013). Micro-tom mutants for functional analysis of target genes and discovery of new alleles in tomato. Plant Biotechnol. 30, 1-7. doi: 10.5511/ plantbiotechnology.13.0622a

Kimbara, J., Yoshida, M., Ito, H., Hosoi, K., Kusano, M., Kobayashi, M., et al. (2012). A novel class of sticky peel and light green mutations causes cuticle deficiency in leaves and fruits of tomato (Solanum lycopersicum). Planta 236, 1559-1570. doi: 10.1007/s00425-012-1719-6

Kimbara, J., Yoshida, M., Ito, H., Kitagawa, M., Takada, W., Hayashi, K., et al. (2013). Inhibition of CUTIN DEFICIENT 2 causes defects in cuticle function and structure and metabolite changes in tomato fruit. Plant Cell Physiol. 54, 1535-1548. doi: 10.1093/pcp/pct100

Klee, H. J., and Giovannoni, J. J. (2011). Genetics and control of tomato fruit ripening and quality attributes. Annu. Rev. Genet. 45, 41-59. doi: 10.1146/ annurev-genet-110410-132507

Kosma, D. K., Parsons, E. P., Isaacson, T., Lü, S., Rose, J. K., and Jenks, M. A. (2010). Fruit cuticle lipid composition during development in tomato ripening mutants. Physiol. Plant. 139, 107-117. doi: 10.1111/j.1399-3054.2009.01342.x 
Kriegshauser, L., Knosp, S., Grienenberger, E., Tatsumi, K., Gütle, D. D., Sørensen, I., et al. (2021). Function of the HYDROXYCINNAMOYLCOA:SHIKIMATE HYDROXYCINNAMOYL TRANSFERASE is evolutionarily conserved in embryophytes. Plant Cell. 33, 1472-1491. doi: 10.1093/plcell/ koab044

Kumar, R., Tamboli, V., Sharma, R., and Sreelakshmi, Y. (2018). NAC-NOR mutations in tomato Penjar accessions attenuate multiple metabolic processes and prolong the fruit shelf life. Food Chem. 259, 234-244. doi: 10.1016/j. foodchem.2018.03.135

Lara, I., Heredia, A., and Domínguez, E. (2019). Shelf life potential and the fruit cuticle: the unexpected player. Front. Plant Sci. 10:770. doi: 10.3389/fpls.2019.00770

Lashbrooke, J., Adato, A., Lotan, O., Alkan, N., Tsimbalist, T., Rechav, K., et al. (2015). The tomato MIXTA-like transcription factor coordinates fruit epidermis conical cell development and cuticular lipid biosynthesis and assembly. Plant Physiol. 169, 2553-2571. doi: 10.1104/pp.15.01145

Lashbrooke, J., Cohen, H., Levy-Samocha, D., Tzfadia, O., Panizel, I., Zeisler, V., et al. (2016). MYB107 and MYB9 homologs regulate suberin deposition in angiosperms. Plant Cell 28, 2097-2116. doi: 10.1105/tpc.16.00490

Leide, J., Hildebrandt, U., Reussing, K., Riederer, M., and Vogg, G. (2007). The developmental pattern of tomato fruit wax accumulation and its impact on cuticular transpiration barrier properties: effects of a deficiency in a beta-ketoacyl-coenzyme A synthase (LeCER6). Plant Physiol. 144, 1667-1679. doi: $10.1104 /$ pp.107.099481

Leide, J., Hildebrandt, U., Vogg, G., and Riederer, M. (2011). The positional sterile (ps) mutation affects cuticular transpiration and wax biosynthesis of tomato fruits. J. Plant Physiol. 168, 871-877. doi: 10.1016/j.jplph.2010.11.014

Lemaire-Chamley, M., Petit, J., Garcia, V., Just, D., Baldet, P., Germain, V., et al. (2005). Changes in transcriptional profiles are associated with early fruit tissue specialization in tomato. Plant Physiol. 139, 750-769. doi: 10.1104/ pp.105.063719

Li, R., Sun, S., Wang, H., Wang, K., Yu, H., Zhou, Z., et al. (2020). FIS1 encodes a GA2-oxidase that regulates fruit firmness in tomato. Nat. Commun. 11:5844. doi: 10.1038/s41467-020-19705-w

Liang, B., Sun, Y., Wang, J., Zheng, Y., Zhang, W., Xu, Y., et al. (2021). Tomato protein phosphatase $2 \mathrm{C}$ influences the onset of fruit ripening and fruit glossiness. J. Exp. Bot. 72, 2403-2418. doi: 10.1093/jxb/eraa593

Martin, L., Romero, P., Fich, E. A., Domozych, D. S., and Rose, J. (2017). Cuticle biosynthesis in tomato leaves is developmentally regulated by abscisic acid. Plant Physiol. 174, 1384-1398. doi: 10.1104/pp.17.00387

Martin, L. B., Sherwood, R. W., Nicklay, J. J., Yang, Y., Muratore-Schroeder, T. L., Anderson, E. T., et al. (2016). Application of wide selected-ion monitoring data-independent acquisition to identify tomato fruit proteins regulated by the CUTIN DEFICIENT2 transcription factor. Proteomics 16, 2081-2094. doi: $10.1002 /$ pmic. 201500450

Matas, A. J., Yeats, T. H., Buda, G. J., Zheng, Y., Chatterjee, S., Tohge, T., et al. (2011). Tissue- and cell-type specific transcriptome profiling of expanding tomato fruit provides insights into metabolic and regulatory specialization and cuticle formation. Plant Cell 23, 3893-3910. doi: 10.1105/tpc.111.091173

Meissner, R., Jacobson, Y., Melamed, S., Levyatuv, S., Shalev, G., Ashri, A., et al. (1997). A new model system for tomato genetics. Plant J. 12, 1465-1472. doi: 10.1046/j.1365-313x.1997.12061465.x

Menda, N., Semel, Y., Peled, D., Eshed, Y., and Zamir, D. (2004). In silico screening of a saturated mutation library of tomato. Plant J. 38, 861-872. doi: $10.1111 /$ j.1365-313X.2004.02088.x

Minoia, S., Petrozza, A., D'Onofrio, O., Piron, F., Mosca, G., Sozio, G., et al. (2010). A new mutant genetic resource for tomato crop improvement by TILLING technology. BMC Res. Notes 3:69. doi: 10.1186/1756-0500-3-69

Mintz-Oron, S., Mandel, T., Rogachev, I., Feldberg, L., Lotan, O., Yativ, M., et al. (2008). Gene expression and metabolism in tomato fruit surface tissues. Plant Physiol. 147, 823-851. doi: 10.1104/pp.108.116004

Moreira, C., Bento, A., Pais, J., Petit, J., Escórcio, R., Correia, V. G., et al. (2020). An ionic liquid extraction that preserves the molecular structure of cutin shown by nuclear magnetic resonance. Plant Physiol. 184, 592-606. doi: $10.1104 /$ pp.20.01049

Nadakuduti, S. S., Pollard, M., Kosma, D. K., Allen, C. Jr., Ohlrogge, J. B., and Barry, C. S. (2012). Pleiotropic phenotypes of the sticky peel mutant provide new insight into the role of CUTIN DEFICIENT2 in epidermal cell function in tomato. Plant Physiol. 159, 945-960. doi: 10.1104/ pp.112.198374
Ofner, I., Lashbrooke, J., Pleban, T., Aharoni, A., and Zamir, D. (2016). Solanum pennellii backcross inbred lines (BILs) link small genomic bins with tomato traits. Plant J. 87, 151-160. doi: 10.1111/tpj.13194

Okabe, Y., Asamizu, E., Saito, T., Matsukura, C., Ariizumi, T., Brès, C., et al. (2011). Tomato TILLING technology: development of a reverse genetics tool for the efficient isolation of mutants from micro-tom mutant libraries. Plant Cell Physiol. 52, 1994-2005. doi: 10.1093/pcp/pcr134

Petit, J., Bres, C., Just, D., Garcia, V., Mauxion, J. P., Marion, D., et al. (2014). Analyses of tomato fruit brightness mutants uncover both cutin-deficient and cutin-abundant mutants and a new hypomorphic allele of GDSL lipase. Plant Physiol. 164, 888-906. doi: 10.1104/pp.113.232645

Petit, J., Bres, C., Mauxion, J. P., Bakan, B., and Rothan, C. (2017). Breeding for cuticle-associated traits in crop species: traits, targets, and strategies. J. Exp. Bot. 68, 5369-5387. doi: 10.1093/jxb/erx341

Petit, J., Bres, C., Mauxion, J. P., Tai, F. W., Martin, L. B., Fich, E. A., et al. (2016). The glycerol-3-phosphate acyltransferase GPAT6 from tomato plays a central role in fruit cutin biosynthesis. Plant Physiol. 171, 894-913. doi: 10.1104/pp.16.00409

Philippe, G., Gaillard, C., Petit, J., Geneix, N., Dalgalarrondo, M., Bres, C., et al. (2016). Ester cross-link profiling of the cutin polymer of wild-type and cutin synthase tomato mutants highlights different mechanisms of polymerization. Plant Physiol. 170, 807-820. doi: 10.1104/pp.15.01620

Philippe, G., Geneix, N., Petit, J., Guillon, F., Sandt, C., Rothan, C., et al. (2020a). Assembly of tomato fruit cuticles: a cross-talk between the cutin polyester and cell wall polysaccharides. New Phytol. 226, 809-822. doi: 10.1111/nph.16402

Philippe, G., Sørensen, I., Jiao, C., Sun, X., Fei, Z., Domozych, D. S., et al. (2020b). Cutin and suberin: assembly and origins of specialized lipidic cell wall scaffolds. Curr. Opin. Plant Biol. 55, 11-20. doi: 10.1016/j.pbi.2020.01.008

Renaudin, J. P., Deluche, C., Cheniclet, C., Chevalier, C., and Frangne, N. (2017). Cell layer-specific patterns of cell division and cell expansion during fruit set and fruit growth in tomato pericarp. J. Exp. Bot. 68, 1613-1623. doi: $10.1093 / \mathrm{jxb} / \mathrm{erx} 058$

Romero, P., and Rose, J. (2019). A relationship between tomato fruit softening, cuticle properties and water availability. Food Chem. 295, 300-310. doi: 10.1016/j.foodchem.2019.05.118

Rothan, C., Bres, C., Garcia, V., and Just, D. (2016) in Tomato Resources for Functional Genomics. eds. M. Causse, J. Giovannoni, M. Bouzayen and M. Zouine (Berlin Heidelberg: Springer), 75-94.

Rothan, C., Diouf, I., and Causse, M. (2019). Trait discovery and editing in tomato. Plant J. 97, 73-90. doi: 10.1111/tpj.14152

Saito, T., Ariizumi, T., Okabe, Y., Asamizu, E., Hiwasa-Tanase, K., and Fukuda, N. (2011). TOMATOMA: a novel tomato mutant database distributing microtom mutant collections. Plant Cell Physiol. 52, 283-296. doi: 10.1093/pcp/ pcr004

Saladié, M., Matas, A. J., Isaacson, T., Jenks, M. A., Goodwin, S. M., Niklas, K. J., et al. (2007). A reevaluation of the key factors that influence tomato fruit softening and integrity. Plant Physiol. 144, 1012-1028. doi: 10.1104/ pp.107.097477

Segado, P., Heredia-Guerrero, J. A., Heredia, A., and Domínguez, E. (2020). Cutinsomes and CUTIN SYNTHASE1 function sequentially in tomato fruit cutin deposition. Plant Physiol. 183, 1622-1637. doi: 10.1104/pp.20.00516

Shi, J. X., Adato, A., Alkan, N., He, Y., Lashbrooke, J., Matas, A. J., et al. (2013). The tomato SISHINE3 transcription factor regulates fruit cuticle formation and epidermal patterning. New Phytol. 197, 468-480. doi: 10.1111/ nph.12032

Shinozaki, Y., Nicolas, P., Fernandez-Pozo, N., Ma, Q., Evanich, D. J., Shi, Y., et al. (2018). High-resolution spatiotemporal transcriptome mapping of tomato fruit development and ripening. Nat. Commun. 9, 364. doi: 10.1038/ s41467-017-02782-9

Smirnova, A., Leide, J., and Riederer, M. (2013). Deficiency in a very-longchain fatty acid $\beta$-ketoacyl-coenzyme a synthase of tomato impairs microgametogenesis and causes floral organ fusion. Plant Physiol. 161, 196-209. doi: 10.1104/pp.112.206656

Szymański, J., Bocobza, S., Panda, S., Sonawane, P., Cárdenas, P. D., Lashbrooke, J., et al. (2020). Analysis of wild tomato introgression lines elucidates the genetic basis of transcriptome and metabolome variation underlying fruit traits and pathogen response. Nat. Genet. 52, 1111-1121. doi: 10.1038/ s41588-020-0690-6 
Szymanski, J., Levin, Y., Savidor, A., Breitel, D., Chappell-Maor, L., Heinig, U., et al. (2017). Label-free deep shotgun proteomics reveals protein dynamics during tomato fruit tissues development. Plant J. 90, 396-417. doi: 10.1111/ tpj. 13490

Tomato Genome Consortium (2012). The tomato genome sequence provides insights into fleshy fruit evolution. Nature 485, 635-641. doi: 10.1038/ nature 11119

Ursache, R., De Jesus Vieira Teixeira, C., Dénervaud Tendon, V., Gully, K., De Bellis, D., Schmid-Siegert, E., et al. (2021). GDSL-domain proteins have key roles in suberin polymerization and degradation. Nat. Plants 7, 353-364. doi: 10.1038/s41477-021-00862-9

Vogg, G., Fischer, S., Leide, J., Emmanuel, E., Jetter, R., Levy, A. A., et al. (2004). Tomato fruit cuticular waxes and their effects on transpiration barrier properties: functional characterization of a mutant deficient in a very-longchain fatty acid beta-ketoacyl-CoA synthase. J. Exp. Bot. 55, 1401-1410. doi: $10.1093 /$ jxb/erh149

Wang, R., Angenent, G. C., Seymour, G., and de Maagd, R. A. (2020). Revisiting the role of master regulators in tomato ripening. Trends Plant Sci. 25, 291-301. doi: 10.1016/j.tplants.2019.11.005

Xin, A., Fei, Y., Molnar, A., and Fry, S. C. (2021). Cutin:cutin-acid endotransacylase (CCT), a cuticle-remodelling enzyme activity in the plant epidermis. Biochem. J. 478, 777-798. doi: 10.1042/BCJ20200835

Xiong, C., Xie, Q., Yang, Q., Sun, P., Gao, S., Li, H., et al. (2020). WOOLLY, interacting with MYB transcription factor MYB31, regulates cuticular wax biosynthesis by modulating CER6 expression in tomato. Plant J. 103, 323-337. doi: $10.1111 /$ tpj. 14733

Yeats, T. H., Buda, G. J., Wang, Z., Chehanovsky, N., Moyle, L. C., Jetter, R., et al. (2012a). The fruit cuticles of wild tomato species exhibit architectural and chemical diversity, providing a new model for studying the evolution of cuticle function. Plant J. 69, 655-666. doi: 10.1111/j.1365-313X. 2011.04820.x

Yeats, T. H., Howe, K. J., Matas, A. J., Buda, G. J., Thannhauser, T. W., and Rose, J. K. (2010). Mining the surface proteome of tomato (Solanum lycopersicum) fruit for proteins associated with cuticle biogenesis. J. Exp. Bot. 61, 3759-3771. doi: 10.1093/jxb/erq194

Yeats, T. H., Huang, W., Chatterjee, S., Viart, H. M., Clausen, M. H., Stark, R. E., et al. (2014). Tomato cutin deficient 1 (CD1) and putative orthologs comprise an ancient family of cutin synthase-like (CUS) proteins that are conserved among land plants. Plant J. 77, 667-675. doi: 10.1111/tpj.12422

Yeats, T. H., Martin, L. B., Viart, H. M., Isaacson, T., He, Y., Zhao, L., et al. (2012b). The identification of cutin synthase: formation of the plant polyester cutin. Nat. Chem. Biol. 8, 609-611. doi: 10.1038/nchembio.960

Zhang, C., Wang, T., Li, J., Zhang, D., Xie, Q., Munir, S., et al. (2021). Functional gain of fruit netted-cracking in an introgression line of tomato with higher expression of the FNC gene. Front. Agric. Sci. Eng. 8, 280-291. doi: 10.15302/J-FASE-2020374

Zhu, G., Wang, S., Huang, Z., Zhang, S., Liao, Q., Zhang, C., et al. (2018). Rewiring of the fruit metabolome in tomato breeding. Cell 172, 249. e12-261.e12. doi: 10.1016/j.cell.2017.12.019

Conflict of Interest: The authors declare that the research was conducted in the absence of any commercial or financial relationships that could be construed as a potential conflict of interest.

Publisher's Note: All claims expressed in this article are solely those of the authors and do not necessarily represent those of their affiliated organizations, or those of the publisher, the editors and the reviewers. Any product that may be evaluated in this article, or claim that may be made by its manufacturer, is not guaranteed or endorsed by the publisher.

Copyright (c) 2021 Petit, Bres, Reynoud, Lahaye, Marion, Bakan and Rothan. This is an open-access article distributed under the terms of the Creative Commons Attribution License (CC BY). The use, distribution or reproduction in other forums is permitted, provided the original author(s) and the copyright owner(s) are credited and that the original publication in this journal is cited, in accordance with accepted academic practice. No use, distribution or reproduction is permitted which does not comply with these terms. 